\title{
Schwannoma parafaríngeo gigante: Diagnóstico diferencial y enfoque terapéutico
}

\author{
Giant parapharyngeal schwannoma: \\ Differential diagnosis and therapeutic approach
}

\author{
L.M. Capitán Cañadas', M.A. Sicilia Gutiérrez', S.L. Martínez Castillo², I.L. Labrot Moleón', \\ D. Sánchez López², E. Valencia Laseca
}

Resumen: Los procesos expansivos de localización parafaríngea representan entre el 0,5 y el 0,8\% de todas las lesiones tumorales de cabeza y cuello. En su diagnóstico diferencial una de las principales entidades que hay que tener en cuenta, por su elevada frecuencia, son las lesiones neurogénicas (25-45\% de incidencia en cabeza y cuello) cuya evolución, lenta en el tiempo, y su crecimiento expansivo, condicionan, en la mayoría de las ocasiones, una mínima repercusión clínica. Una correcta anamnesis acompañada de pruebas de imagen (TC, RM, arteriografía) orienta el diagnóstico de este tipo de lesiones de origen neurógeno. La opción terapéutica más consensuada es la exéresis quirúrgica, siendo necesaria en determinadas ocasiones la embolización tumoral en las 24-48 horas previas a la intervención.

Presentamos un caso de schwannoma parafaríngeo gigante, prácticamente asintomático y de aproximadamente cinco años de evolución, haciendo especial hincapié en su manejo diagnóstico y terapéutico, así como una revisión actualizada de los posibles diagnósticos diferenciales de masas parafaríngeas y de los protocolos de actuación frente a este tipo de lesiones.

Palabras clave: Espacio parafaríngeo; Neurinomas de cabeza y cuello; Schwannoma.

Recibido: 4 de julio de 2003

Aceptado: 25 de mayo de 2005
Abstract: Expansive processes of parapharyngeal location represent between $0.5 \%$ and $0.8 \%$ of all tumorous lesions in the head and neck. In their differential diagnosis, one of the main considerations that must be kept in mind due to their high frequency are neurogenic lesions (25-45\% incidence in the head and neck) with an evolution that is slow and expansive growth, clinical repercussions are minimal in the majority of cases. A correct anamnesis, accompanied by imaging tests (CT, MR, arteriography), is informative for the diagnosis of this type of lesion with a neurogenic origin. The most agreed upon therapeutic option is surgical removal with embolization of the tumor 24-48 hours before the operation being necessary in certain situations.

We present a case of giant parapharyngeal schwannoma, that was practically asymptomatic, and had been developing for approximately 5 years, putting special emphasis on diagnostic and therapeutic management, as well as an updated review of the possible differential diagnoses of parapharyngeal masses and the protocols for working with this type of lesion.

Key words: Parapharyngeal space; Head and neck neurinoma; Schwannoma.

\footnotetext{
1 Médico residente.

2 Médico adjunto.

3 Jefe de Servicio.

Servicio de Cirugía Oral y Maxilofacial. Hospital Universitario Virgen de las Nieves.

Granada. España.
}

\section{Correspondencia:}

Luis Miguel Capitán Cañadas

Servicio de Cirugía Oral y Maxilofacial

Hospital Universitario Virgen de las Nieves. CRT.

Carretera de Jaén s/n. Granada, España

e-mail: luismxf@hotmail.com 


\section{Introducción}

Las lesiones tumorales de localización parafaríngea presentan una escasa incidencia, representando entre el 0,5 y el $0,8 \%$ de todas las tumoraciones de cabeza y cuello. ${ }^{1,2}$ Aproximadamente el $80 \%$ presentan un comportamiento benigno..$^{2-4}$ La singularidad de dichas lesiones deriva de su compleja situación anatómica y de la clínica con la que suelen debutar, siendo en la mayoría de los casos inespecífica y casi siempre derivada del efecto compresivo producido por la lesión sobre oro y rinofaringe.

Es de sobra conocida la anatomía del espacio parafaríngeo, 2,5 aun así conviene recordar las importantes relaciones vasculonerviosas del mismo. La fascia que se extiende desde la estiloides hasta el músculo tensor del velo del paladar ha sido la referencia clásica para la división del espacio parafaríngeo en área pre y retroestiloidea. En la primera podemos encontrar parte del lóbulo profundo de la glándula parótida y una pequeña rama del quinto par craneal que la atraviesa y da inervación al tensor del velo del paladar. El principal contenido de este espacio es graso y la gran mayoría de tumores que podemos encontrar en él son lesiones salivares, tumores neurogénicos y lipomas. ${ }^{6}$ El área retroestiloidea contiene la arteria carótida interna y la vena yugular interna así como los pares craneales IX, X, XI y XII, la cadena simpática cervical, nódulos linfáticos y tejido glómico. En el citado espacio podemos encontrar lesiones derivadas de cualquiera de las estructuras que contiene.

En la clasificación de lesiones parafaríngeas encontramos tres grupos, ordenados de mayor a menor en función de su frecuencia de aparición.

El grupo más frecuente lo constituyen tumores derivados de glándulas salivares (40-50\%); el segundo lugar lo ocupan los tumores neurogénicos (17-25\%); el tercer grupo se encuentra formado por paragangliomas (10-15\%). En el grupo de lesiones de origen neurogénico de localización parafaríngea, encontramos tres tipos de lesiones, ordenadas también por orden decreciente de aparición: schwannomas o neurilemomas, quemodectomas y neurofibromas.

Los schwannomas son tumores histológicamente benignos, derivados de la vaina de Schwann; el $25-45 \%$ de los schwannomas extracraneales se presentan en cabeza y cuello, siendo su localización preferente laterocervical. Su evolución clínica es lenta en el tiempo, lo que motiva un diagnóstico tardío en la mayoría de ocasiones. A la hora de intentar establecer una orientación diagnóstica es importante contar con una adecuada anamnesis y apoyarnos en pruebas de imagen de alta resolución (Tomografía computerizada, Resonancia magnética y Arteriografía carotídea). El empleo de técnicas citohistológicas de diagnóstico continúa siendo motivo de controversia, estando limitado el empleo de biopsia a casos excepcionales. El tratamiento de elección de los neurilemomas es la exéresis quirúrgica, precedida, si el caso lo precisa, de embolización prequirúrgica $24-48$ horas antes de la cirugía. Por norma general no es necesario realizar otros tratamientos complementarios, siendo el índice de recurrencia después de la cirugía muy bajo. Es necesario el estudio anatomopatológico de la lesión para confirmar el diagnóstico de schwannoma.

\section{Introduction}

Tumor lesions with a parapharyngeal location are very unusual, representing between 0.5 and $0.8 \%$ of all tumors of the head and neck. 1,2 The behavior of approximately $80 \%$ is benign. ${ }^{2-4}$ These lesions are unusual as a result of their complex anatomic position and of their appearance at the clinical onset, which is in most cases unspecific as a result nearly always of the compression effect produced by the lesion on the oro and rhinopharynx.

The anatomy of the parapharyngeal space is well known, 2,5 although we should remember the important vasculonervous network within it. The fascia that extends from the styloid process to the tensor muscle of the vellum of the palate has been the reference point traditionally for dividing the parapharyngeal space into the pre and retrostyloid areas. In the first area we find part of the deep lobe and the parotid gland and a small branch of the fifth pair of cranial nerves that crosses and provides innervation to the vellum tensor of the palate. The principal content of this space is fat and the large majority of tumors that we find here are salivary lesions, neurogenic tumors and lipomas. ${ }^{6}$ The retrostyloid area contains the internal carotid artery and the internal jugular vein as well as the cranial pairs of nerves $I X$, $X, X I$ and XII, the sympathetic chain, lymphatic nodes and glomic tissue. In this space we may find lesions originating from any of the structures that are contained in this area.

In the classification of parapharyngeal tumors we find three groups that are arranged from larger to smaller according to the frequency with which they appear.

The most common group is made up of tumors originating in the salivary glands (40-50\%), in second place are neurogenic tumors (17-25\%) and the third group is made up of paragangliomas (10-15\%). In the group of lesions with a neurogenic origin located in the parapharyngeal space, we find three types of lesions that are also, in decreasing order: schwannomas or neurilemomas, chemodectomas and neurofibromas.

Schwannomas are histologically benign tumors, derived from the Schwann sheath; 25-45\% of schwannomas are extracranial and they appear in the head and neck, the most favored locations being laterocervial. Their clinical development is slow, which leads to a diagnosis that is tardy on most occasions. On trying to establish their diagnostic orientation it is important to rely on suitable anamnesis and imaging studies with a high resolution (Computed Axial Tomography, Nuclear Magnetic Resonance and Carotid Arteriography. The use of cytohistological diagnostic techniques continues being controversial, with biopsies being used in exceptional cases. The treatment of choice for neurilemomas is surgical excision, preceded if need be by preosurgical embolization 24-48 hours before surgery. Generally, complementary therapy is not necessary as the recurrence rate after surgery is very low. Anatomopathological study of the lesion is needed in order to confirm the diagnosis of schwannoma. 


\section{Caso clínico}

Paciente mujer de 31 años de edad y sin antecedentes personales de interés que acude al servicio de Cirugía Oral y Maxilofacial del Hospital Universitario Virgen de las Nieves de Granada por presentar molestias cervicales inespecíficas y rinolalia persistente de varios años de evolución.

En la exploración intraoral la paciente presenta abombamiento de pared lateral derecha orofaríngea con discreta desviación de úvula, sin odinodisfagia ni sensación disneica acompañante (Fig. 1). La exploración cervical no aporta datos significativos.

Frente a la sospecha de un posible proceso expansivo de localización retroparafaríngea se realizan estudios de imagen mediante Tomografía Computerizada (TC) y Resonancia Magnética (RM) que revelan la existencia de una masa ovalada $(5 \times 4 \times 7 \mathrm{~cm})$ con bordes bien definidos y de localización parafaríngea derecha con áreas necrosadas en su polo superior y con abundante vascularización capsular (Figs. 2 y 3). Los posibles diagnósticos radiológicos son compatibles con lesión de tipo hamartomatoso, lesión de estirpe linfoide, tumoración glómica o neurogénica. Ante la evidencia radiológica de una lesión altamente vascularizada se realiza arteriografía de arteria carótida común y selectiva de arteria carótida externa derecha, en la que se observa dependencia por parte de la masa de la arteria faríngea ascendente derecha (Fig. 4).

Con estos datos y prescindiendo de estudios diagnósticos citohistológicos, por el evidente riesgo de sangrado, se decide practicar embolización de la lesión tras descartar, mediante estudios hormonales, secreción autónoma catecolaminérgica por parte de la misma. Tras conseguir una devascularización tumoral de aproximadamente un $90 \%$ se procede a la exéresis quirúrgica del tumor a las 24 horas postembolización. Mediante abordaje transcervical, sin necesidad de mandibulotomía, se accede a espacio parafaríngeo derecho donde se aprecia una masa encapsulada dependiente de estructuras nerviosas (pares craneales bajos) que puede ser extirpada en su totalidad con preservación vasculonerviosa íntegra (Fig. 5)

Macroscopicamente se trata de una masa sólida de aspecto parduzco y consistencia elástica con un tamaño de $7.8 \times 5.5 \times 5 \mathrm{~cm}$. Al corte presenta zonas quísticas necróticas. El estudio histológico de la pieza operatoria diagnostica la lesión como schwannoma mixto (Antoni A y B) (Fig. 6).

\section{Clinical case}

Female patient, 31 years old, with no medical history of interest, attended the Oral and Maxillofacial service of the University Hospital Virgen de las Nieves Granada as she had unspecific neck pain and persistent rhinolalia that had been developing for some years.

During the intraoral examination a bulging of the right lateral oropharyngeal wall was noted and the uvula was slightly displaced. There was no odynodysphagia nor was there any accompanying dyspneic sensation (Fig. 1) The cervical examination was not significant in any way. As a possible expansive process in the retro-pharynx was suspected, tests with Computed Axial Tomography (CT) and Nuclear Magnetic Resonance (MR) were carried out that revealed the existence of an oval mass (measuring $5 \times 4$ $x 7 \mathrm{~cm}$ ). It had well-defined borders and it was located in the right parapharyngeal space. The upper part had necrotic areas and it had an abundant vascular supply (Figs. 2, 3a and b). The possible radiological diagnoses were compatible with a hamartomatous lesion, a lesion of a lymphoid nature, and a glomic or neurogenic lesion. With the radiological evidence of a highly vascular lesion, an arteriography of the common carotid artery was carried out together with a selective arteriography of the right external carotid artery, which showed that the mass was supplied by the right ascending pharyngeal artery (Fig. 4).

With this data cyto-histological diagnostic tests were dispensed with because of a risk of bleeding, and it was decided that the lesion should be embolized as, after hormonal studies, catecholaminergic autonomous secretion was ruled out. After achieving tumoral devascularization of approximately 90\%, the tumor was then removed 24 hours after embolization. Using a transcervical approach, there being no need for a mandibulotomy, the right parapharyngeal space was accessed and an encapsulated mass was observed that depended on nervous structures (low cranial nerves) 
Tras seguimiento de once meses la paciente presenta remisión clínica y radiológica del proceso (Figs. 7 y 8 ).

\section{Discusión}

La totalidad de artículos revisados, 1,2,4,7 coinciden en clasificar las masas tumorales del espacio parafaríngeo en tres grupos: tumores de glándulas salivales: principalmente derivados del lóbulo parotídeo profundo, tumores neurogénicos: en su mayor parte schwannomas o neurilemomas y paragangliomas. Con menor frecuencia se describe, ${ }^{2,4}$ un cuarto grupo miscelánea que agrupa distintos tipos de lesiones: hemangiomas, quistes branquiales, nódulos linfáticos, metástasis tumorales, aneurismas, cordomas, meningiomas y sarcomas.

Dentro de las tumoraciones neurogénicas, el grupo más frecuente está constituido por schwannomas o neurilemomas, seguidos en frecuencia por quemodectomas y neurofibromas. ${ }^{2}$ Descritos por primera vez en 1910 por Verocay (en Ortiz-Hidalgo, 2004), ${ }^{8}$ y tipificados histológicamente en 1920 por Antoni, 9 los schwannomas o neurilemomas son tumores originados a partir de la vaina nerviosa de recubrimiento de los axones del sistema nervioso periférico o vaina de Schwann. Según sus características histológicas encontramos dos grupos: Antoni A, caracterizados por presentar agrupaciones densas de células de Schwann con núcleos en empalizada que dan lugar a formaciones características denominadas cuerpos de Verocay y Antoni B, con tendencia a presentar hipocelularidad y con una disposición celular francamente irregular. En el 47\% de los schwannomas encontramos formas mixtas, ${ }^{10}$ (Antoni $A$ y $B$ ). Se han descrito, ${ }^{11}$ otras variedades histológicas (schwannomas melanóticos o angiomatosos) mucho menos frecuentes.

El $10 \%$ de los schwannomas son extracraneales y de éstos el $25-45 \%$ se presentan en cabeza y cuello, 2,12 principalmente en la región laterocervical. El 50\% de los neurilemomas parafaríngeos tienen su origen en el nervio vago, ${ }^{2,13}$ siendo la cadena simpática cervical el segundo lugar de asentamiento de schwanno-
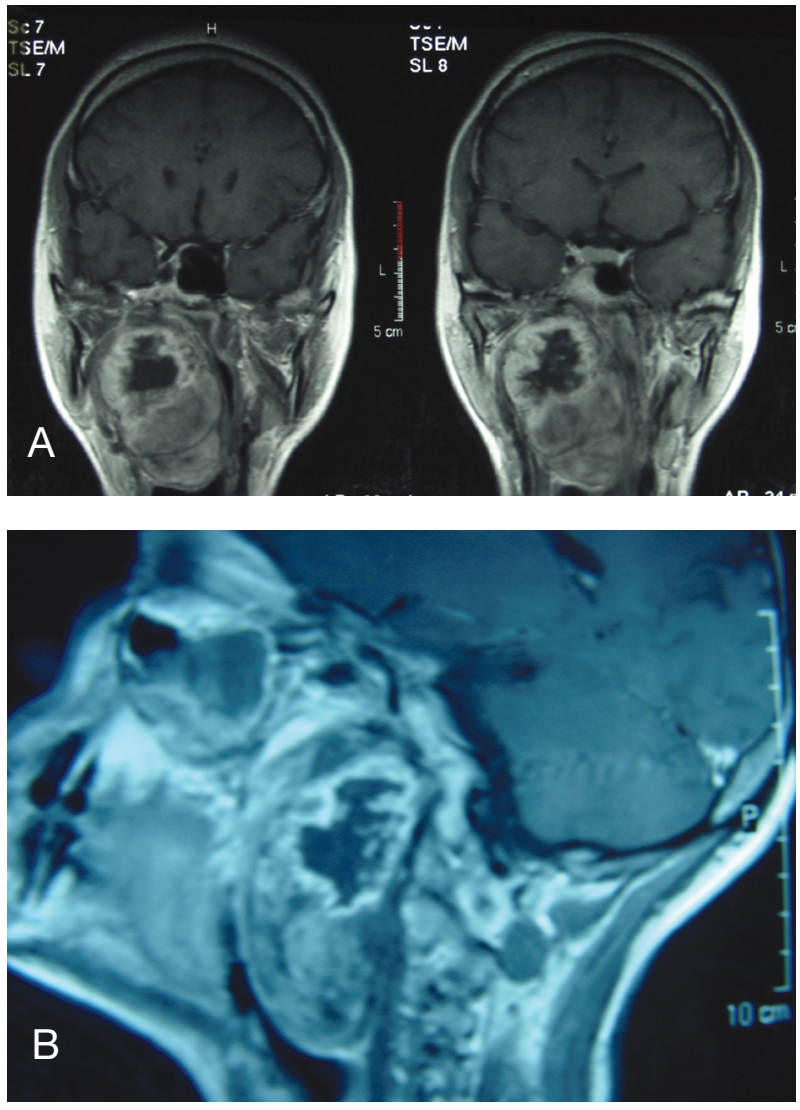

Figura 3. Imágenes de RM sagital (A) y coronal (B) de la lesión. Figure 3. Sagittal (B) and coronal (A) MR images of the lesion.

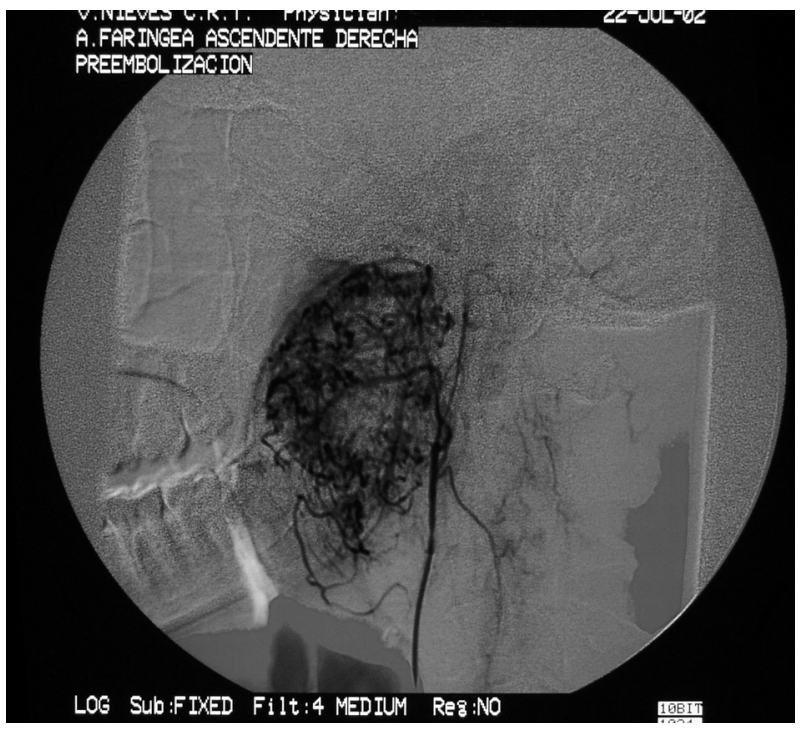

Figura 4. Gran teñido angiográfico de la lesión que hace precisa embolización prequirúrgica.

Figure 4. Large angiographic stain of the lesion that requires presurgical embolization.

that could be completely removed with total preservation of the vasculonervous network (Fig. 5).

Macroscopically it was a solid mass with a brownish color. It had an elastic consistency and measured $7.8 \times 5.5 \times 5$ $\mathrm{cm}$. On cutting into it, cystic necrotic areas appeared. The diagnosis of the lesion by histological study of the surgical sample was of a mixed schwannoma (Antoni A and B) (Fig. 6).

After a follow-up of the patient of eleven months there appeared to be a clinical and radiological remission of the process (Figs. 7 and 8).

\section{Discussion}

All the articles revised 1,2,4,7 are in agreement as to the classification of the tumor masses of the pharyngeal space into three groups: salivary gland tumors: originating principally in the deep parotid lobe, neurogenic tumors: mostly schwannomas or neurilemomas and paragangliomas. To a lesser extent are described, 2,4 a fourth miscellaneous group that includes different types of lesions: hemangiomas, branchial cysts, lymphatic nodes, tumor metastases, aneurisms, chordomas, meningiomas and sarcomas. Within regard to neurogenic tumors, the most common group consists in schwannomas or neurilemomas, followed in order of frequency by chemodectomas and neurofibromas. ${ }^{2}$ First described in 1910 by Verocay (in OrtizHidalgo, 2004) $)^{8}$ and histologically typified by Antoni9 in 1920, schwannomas or neurilemomas are tumors that originate in the nervous sheath that 
mas más frecuente. ${ }^{14}$ No hay establecido un rango de edad predominante para la aparición de este tipo de lesiones. En la distribución por sexos no parece existir predominancia por ninguno de los dos géneros; así autores como Torossian y Gilmer-Hill,10,15 hablan de predominio femenino; Hood, 16 documenta una mayor frecuencia de presentación en hombres y en las series de Peter Pang y Maran,1,5 encontramos igualdad de presentación entre la población masculina y femenina con unos índices hombre-mujer de $15: 16$ y $14: 15$, respectivamente. No parecen haberse encontrado factores de riesgo predisponentes. ${ }^{10}$ En pacientes jóvenes con presencia de schwannoma debe descartarse la existencia de neurofibromatosis tipo II. ${ }^{10}$

Son tumores generalmente benignos, ${ }^{2,3}$ aunque la presencia de dolor o afectación nerviosa debe alertar de una posible transformación maligna. 2,7 Su comportamiento clínico es silente y suele estar asociado a fenómenos compresivos secundarios al crecimiento progresivo y lento del tumor. El síntoma más común, 2,7,10 es la presencia de una masa de crecimiento lento no dolorosa, aunque en determinadas ocasiones pueden mimetizar el comportamiento clínico de otras patologías tales como metástasis tumorales o procesos infecciosos. ${ }^{7}$ No suelen comprometer al nervio de origen, por lo que es poco frecuente la sintomatología por afectación nerviosa. En pacientes con schwannomas de largo tiempo de evolución, se han descrito ocasionalmente déficits neurológicos leves y reversibles. ${ }^{17}$

Aunque el protocolo diagnóstico y el manejo terapéutico de los neurilemomas coincide en líneas generales con el del resto de tumoraciones parafaríngeas, ${ }^{2,18}$ conviene repasarlo de manera individualizada y prestar atención a los pormenores vinculados con este tipo de lesiones.

En el diagnóstico de tumoraciones neurogénicas parafaríngeas, la mayoría de autores plantean el empleo de técnicas de imagen, principalmente Resonancia Magnéticar, ${ }^{19}$ y Tomografía Computerizada1,20,21 como primordial. La RM con gadolinio es posiblemente la técnica radiológica de elección, 19,20,22 ya que permite localizar el tumor en el compartimento pre o retroestiloideo, estudiar las relación con estructuras vasculonerviosas anexas al mismo y precisar características inherentes a la propia lesión (grado de vascularización, consistencia, tamaño). Las imágenes obtenidas con TC permiten además estudiar la relación del tumor con la base crane-

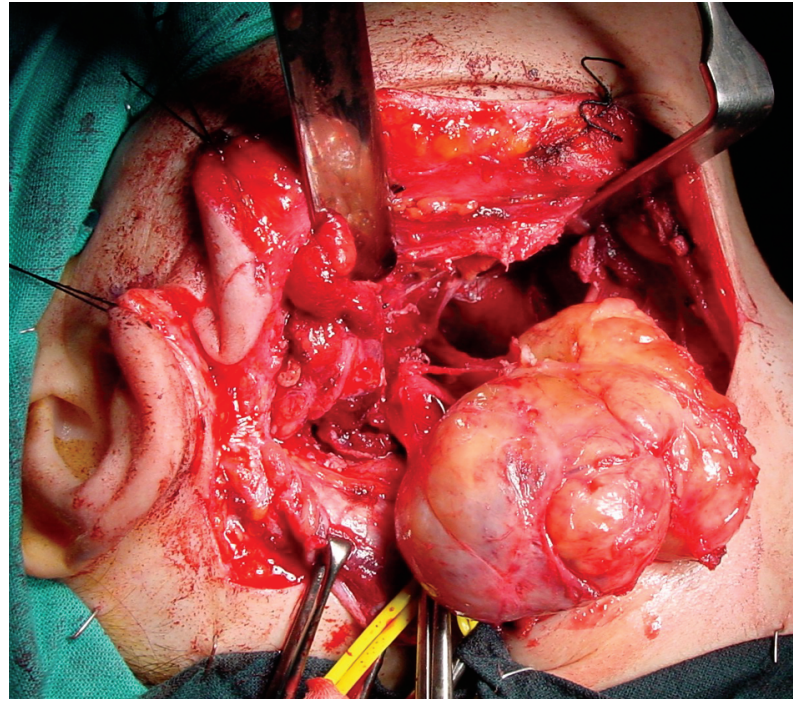

covers the axons of the peripheral nervous system or Schwann sheath. According to the histological characteristics, we find two groups: Antoni A, which is characterized a dense groups of Schwann cells with nuclear palisading leading to formations that are typically called Verocay bodies, and Antoni $B$. These tend to be hypocellular and their arrangement is clearly irregular. In $47 \%$ of cases, the schwannomas found are mixed in shape, 10 (Antoni A and B). Other histological varieties have been described much less frequently, ${ }^{11}$ (melanotic or angiomatous schwannomas). Of the schwannomas, $10 \%$ are extracranial and of these 25-45\% appear in the head and neck, 2,12 principally in the laterocervical area. Of the parapharyngeal neurilemomas, $50 \%$ originate in the vagus nerve, ${ }^{2,13}$ with the cervical sympathetic chain being the second most common location for schwannomas. ${ }^{14}$ There is no predominant age range associated with the appearance of this type of lesion. In the distribution according to sex neither of the two types appears to predominate. Authors such as Torossian and Gilmer-Hill, 10,15 report a predominance in females; Hood, ${ }^{16}$ documented a greater frequency in males and, in Peter Pang and Maran's series 1,5 they appeared equally in the male and female population with male-female ratios of 15:16 and 14:15 respectively. Predisposition and risk factors do not appear to have been found. 10 In young patients with schwannomas the existence of type II nerofibromatosis, ${ }^{10}$ should be ruled out.

These tumors are generally benign, ${ }^{2,3}$ although the presence of pain or nerve damage should alert us to a possible malignant transformation. 2,7 Their clinical behavior is silent, there tending to be an association with a phenomena of secondary compression as a result of the progressive and slow growth of the tumor. The most common symptom, 2,7,10 is the presence of a slow growing, painless mass, although on certain occasions the clinical behavior of other pathologies such as tumor metastases or infectious processes can be 
al. 2,21 El uso diagnóstico de la arteriografía está aconsejado ante la sospecha radiológica de lesiones con alta vascularización. ${ }^{23}$ El estudio citohistológico mediante punción aspiración con aguja fina [PAAF] puede aportar datos significativos, ${ }^{2,24}$ quedando reservado su uso para aquellas tumoraciones en las que tengamos certeza de su naturaleza sólida gracias al empleo de las ya citadas técnicas de imagen. Para su realización se propone la vía transoral, 24,25 como la más adecuada. En la reciente serie de 24 casos publicada por Oliai y cols. ${ }^{24}$ no se describen complicaciones tras la realización de PAAF diagnósticos en masas parafaríngeas de naturaleza no vascular (un diagnóstico citológico de schwannoma). El empleo de biopsia prequirúrgica está contraindicado en la mayoría de ocasiones, ${ }^{2}$ por la complejidad anatómica del abordaje, por el riesgo de ruptura y hemorragia intratumoral y por la posibilidad de crear adherencias fibrosas entre la cápsula del tumor y la pared mucosa faríngea, lo que puede crear alguna dificultad en la posterior exéresis tumoral.

En neurilemomas con abundante vascularización puede ser necesario el empleo de embolización prequirúrgi$\mathrm{Ca}^{20,23}$ ya que minimiza el riesgo de hemorragia intraoperatoria así como la lesión de estructuras vasculonerviosas adyacentes al tumor, por lo cual disminuimos considerablemente la morbilidad operatoria. En aquellos casos en los que no tengamos certeza de encontrarnos frente a un schwannoma, y en previsión de un posible diagnóstico de paranganglioma, puede resultar conveniente descartar la producción catecolaminérgica autónoma por parte del tumor, ${ }^{26}$ (en concreto, estudio de ácido vanilmandélico, metanefrinas, dopamina, epinefrina y norepinefrina en orina y determinación del nivel plasmático de catecolaminas ${ }^{27,28}$ antes de llevar a cabo la embolización, de manera que evitemos la aparición de posibles cuadros hipertensivos y arritmias de difícil control durante la cirugía. ${ }^{20}$

El tratamiento de elección es la exéresis quirúrgica del tumor, $1,2,4,7,10,16,20$ y aunque se propugnan varias vías de

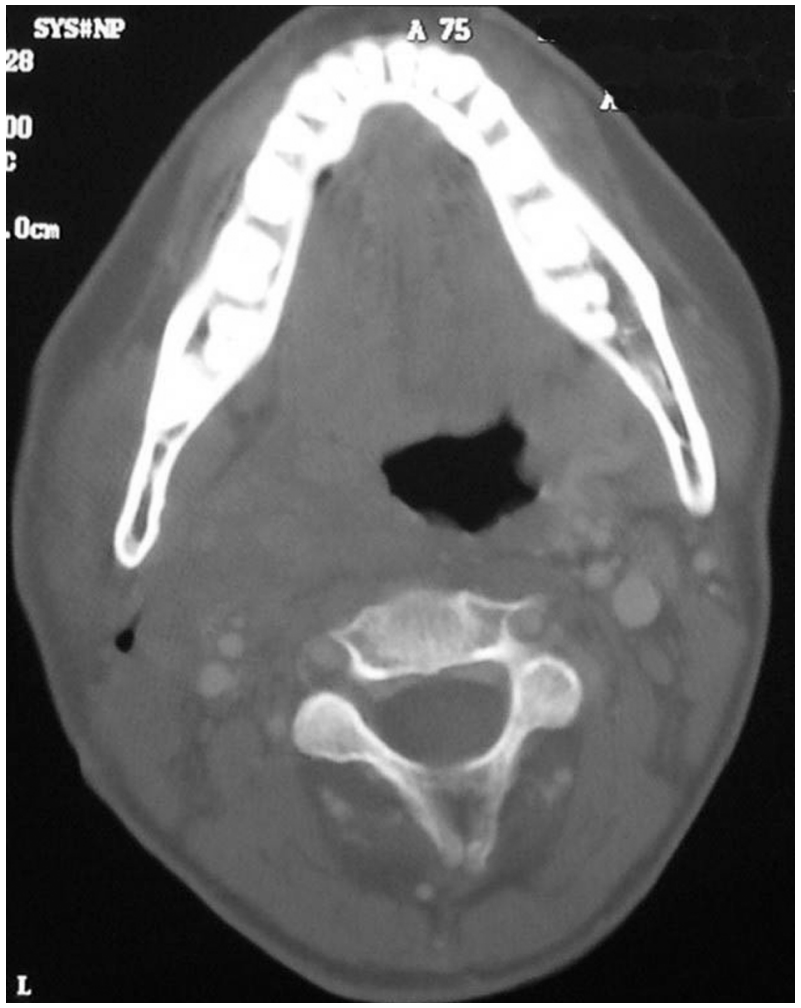

Figura 7. TC axial de control postquirúrgico.

Figure 7. Axial CT scan during postsurgical tests.

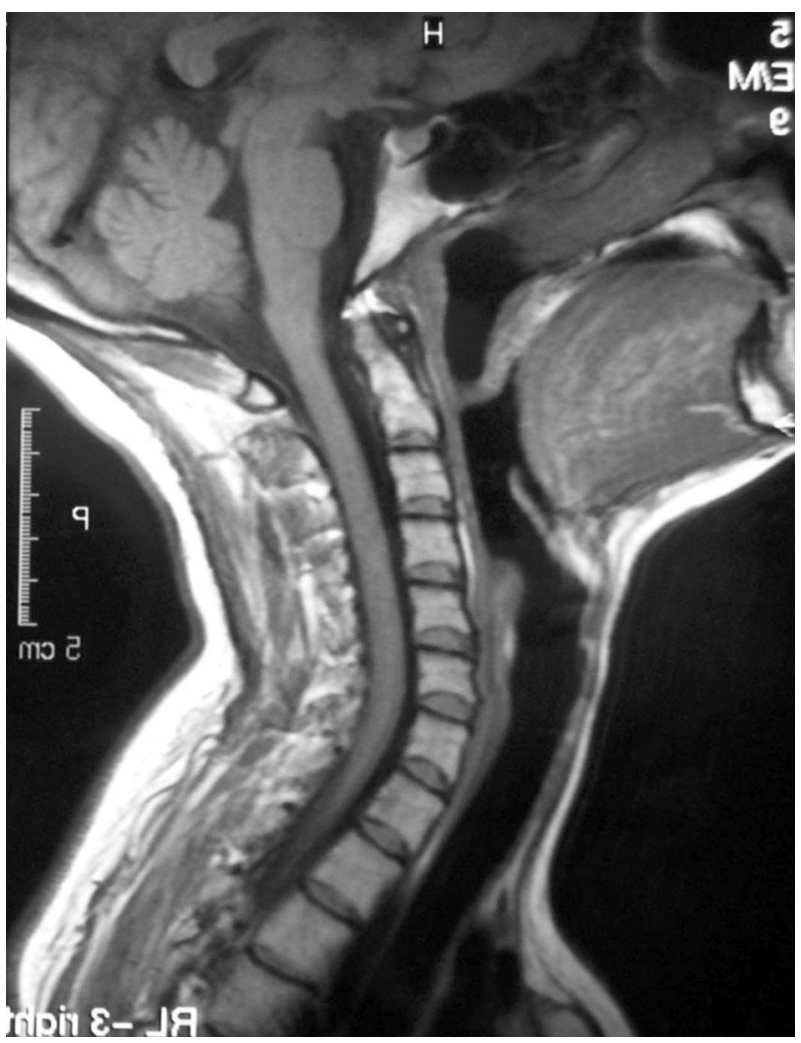

Figura 8. RM sagital de control postquirúrgico.

Figure 8. Sagittal MR during postsurgical tests. copied. ${ }^{7}$ The nerve of origin is not normally affected, and symptoms as a result of nerve damage are not very common. In patients with schwannomas that have been evolving for a long time, slight reversible neurological deficiencies have been described. ${ }^{17}$

Although the diagnostic protocol and therapeutic management of neurilemomas coincides generally with the rest of the parapharyngeal tumors, 2,18 it should be checked individually together with all the details linked to this type of lesion.

With regard to the diagnosis of parapharyngeal neurogenic tumors, most authors consider the use of imaging techniques, principally Nuclear Magnetic Resonance, ${ }^{19}$ and Computed Axial Tomography, 1,20,21 as being of fundamental importance. NMR with gadolinium is possibly the radiological technique of choice, 19,20,22 as it allows locating the tumor in the pre or retrostyloid compartment, studying the relationship with vasculonervous structures beside it, and identifying more precisely the particular characteristics of the lesion (degree of vascularization, consistency, size). The images obtained with the CT scan allow studying the relationship with the skull base. ${ }^{2,21}$ The use of arteriographies for diagnostic purposes is advised when there is a radiological suspicion of highly vascularized lesions. ${ }^{23}$ Cytohistological study by means of fine needle aspiration (FNA) can provide significant data, ${ }^{2,24}$ and it is used only for tumors when we are sure of the mass being solid, once the imaging tech- 
abordaje (transoral, 2,29 transcervical con o sin mandibulotomía, 2,30 cervicoparotídeo, ${ }^{18}$ transparotideo, ${ }^{31}$ o cervico-transfaringeo) ${ }^{18}$ la mayoría de los autores coinciden en la vía transcervical como la más apropiada, 2,10,20,32 y la de mejores resultados quirúrgicos. ${ }^{1}$ En determinadas ocasiones, tales como pacientes ancianos o con patología sistémica que contraindique el uso de anestesia, en caso de tumores irresecables o en caso de pacientes que no asuman la morbilidad intraoperatoria que conlleva la cirugía, puede optarse por tratamiento con radioterapia. 2,20

\section{Bibliografía}

1. Peter Pang K, Goh C, Ming Tan H. Parapharyngeal space tumours: an 18 year review. J Laryngol Otol 2002;116:170-5.

2. Olsen KD. Tumors and surgery of the parapharyngeal space. Laryngoscope 1994; 104(suppl 63).

3. Lawson VG, LeLiever WC, Makerewich LA. Unusual parapharyngeal lesions. I Otolaryngol 1979;8:241-9.

4. Andratschke M, Helmberguer R, Mess K. Differential diagnosis of parapharyngeal mass. Laryngorhinootologie 2000;79:174-9.

5. Maran AGD, Mackenzie IJ, Murray JAM. The parapharyngeal space. J Laryngol Otol 1984;98:371-80.

6. Curtin HD. Separation of the masticator space from the parapharyngeal space. Radiology 1987; 163:195-204.

7. Leu Y-S, Chang K-C. Extracranial head and neck schwannomas: A review of 8 years experience. Acta Otolaryngol 2002;122:435-7.

8. Ortiz-Hidalgo C. Jose Verocay. Verocay neurinomas and bodies and other contributions to medicine. Rev Neurol 2004;39:487-91.

9. Antoni NRI, Bergmann JF. Uber ruchenmarkstumoren und neurofibrome studien zur patologischen anatomie und embryogenese mit einem klinische ausgang munchen. Munchen: J. F. Bergman; 1920.

10. Torossian JM, Beziat JL, Abou Chevel N, Devouassoux-Shisheboran M, Fisher G. Extracranial cephalic schwannomas: a series of 15 patients. / Craniofacial Surgery 1999;10:389-94.

11. White W, Shiu MH, Rosemblum MK. Cellular schwannomas. A clinical pathologic study of 57 patients and 58 tumours. Cancer 1990;66:1266-75.

12. Thurnher D, Quint C, Pammer J, Schima W. Dysphagia due to a large schwannoma of the oropharynx. Arch Otolaryngol Head Neck Surg 2002;128:850-2.

13. Maniglia AJ, Chandler JR, Goodwin WJ. Schwannomas of the parapharyngeal space and jugular foramen. Laryngoscope 1979;89:1405-14.

14. Myssiorek DJ, Silver CE, Valdes ME. Schwannoma of the cervical sympathetic chain. J Laryngol Otol 1988;102:962-5.

15. Gilmer-Hill HS, Kline DG. Neurogenic tumors of the cervical vagus nerve: report of four cases and review of the literature. Neurosurgery 2000;46:1498-503.

16. Hood RJ, Reibel JF, Jensen ME, Levine PA. Schwannomas of the cervical sympathetic chain: The Virginia experience. Ann Otol Rhinol Laryngol 2000;109:48-51.

17. Mc Irath DC, Remine WH, Devine KD. Tumors of the parapharyngeal region. Surg Gynecol Obstet 1963;116:88-94.

18. Olsen KD. Surgical approach to tumors of the parapharyngeal space. Otorhinolaryngol Head Neck Surg 1990;3145-50.

19. Som PM, Curtin HD. Lesions of the parapharyngeal space. Role of MR imaging. Otolaryngol Clin North Am 1995;28:515-42.

20. Eisele D, Netterville J, Hoffman HT, Gantz BJ. Parapharyngeal space masses. Head Neck Controversies 1999;21:154-9. niques previously mentioned have been used. The transoral approach, 24,25 is suggested as the most appropriate. In a recent series of 24 cases published by Oliai et al, ${ }^{24}$ no complications were described following FNA diagnosis of a parapharyngeal mass that was non-vascular (the cytological diagnosis was of schwannoma). The use of a presurgical biopsy is contraindicated in most instances, ${ }^{2}$ due to the anatomical complexity of the approach, the risk of rupture and intratumor hemorrhage, and of the possibility of creating a fibrous adherence between the capsule of the tumor and the mucosa of the pharyngeal wall leading to difficulties with the later removal of the tumor.

With regard to neurilemomas with abundant vascularization, it may be necessary to use a presurgical embolization technique, ${ }^{20,23}$ due to the risk of intraoperative hemorrhaging as well as damage to vasculonervous structures adjacent to the tumor, so that surgical morbidity is, as a result, considerably reduced. In those cases where we are not completely sure of the lesion being a schwannoma, and in order to prepare for a possible diagnosis of paranganglioma, it may be convenient to rule out the autonomous catecholaminergic secretion of the tumor, ${ }^{26}$ (more specifically, with a urine test for vanillymandelic acid, metanephrines, dopamine, epinephrine and norepinephrine and determining the plasma level of the catecholamines, ${ }^{27,28}$ before carrying out embolization, so that the appearance of possible symptoms of hypertension and arrhythmias during the surgical procedure, which are difficult to control, ${ }^{20}$ are avoided.

The treatment of choice is the surgical removal of the tumor, 1,2,4,7,10,16,20 and although various methods of approach are proposed (transoral, ${ }^{2,29}$ transcervical with or without a mandibulectomy, ${ }^{2,30}$ cervicoparotid, 18 transparotid, ${ }^{31}$ or cervico-transpharyngeal), 18 most authors coincide as to the transcervical approach being the most appropriate, 2,10,20,32 and the one with better surgical results. ${ }^{1}$ In certain cases such as with elderly patients or those with a systemic pathology where the use of anesthesia is contraindicated, in cases of tumors that cannot be resectioned or in cases of patients that will not accept the intraoperative morbidity that the surgery involves, treatment with radiotherapy can be opted for. 2,20 
21. Whyte AM, Hourihan MD. The diagnosis of tumours involving the parapharyngeal space by CT. Br J Radiol 1989;62:526-31.

22. Cross RR, Saphiro MD, Som PM. MRI of the parapharyngeal space. Radiol Clin North Am 1989;27:353-78.

23. Abramowitz J, Dion JE, Jensen ME. Angiographic diagnosis and management of head and neck schwannomas. Am J Neuradiol 1991;12:977-84.

24. Oliai BR, Sheth S, Burrougho F. Parapharyngeal space tumors: A cytopathological study of 24 cases on fine-needle aspiration. Diag Cytopathol 2005;32:11-5.

25. Allison RS, Van der Waal I, Snow GB. Parapharyngeal tumours: A review of 23 cases. Clin Otolaryngol 1989;6:92-7.

26. Olsen KD. Complications of surgery of the parapharyngeal space. Complications in head and neck surgery. D.W. Eisele (Ed). Mosby Year Book, 1992.
27. Olsen KD. Parapharyngeal space tumors. Current therapy in otolaryngology head and neck surgery (5th ed) G.A. Gates (Ed). 1992

28. Carrau RL, Myers EN, Johnson JT. Management of tumors arising in the parapharyngeal space. Laryngoscope 1990;100:583-9.

29. Abemayor E, Lufkin R. Enhancing acces to the parapharyngeal space. The laryngoscope 2002;112:757-9.

30. Hamza A, Fagan JJ, Weissman JL, Myers EN. Neurilemomas of the parapharyngeal space. Arch Otolaryngol Head Neck Surg 1997;123: 622-6.

31. Bass RM. Approaches to the diagnosis and treatment of tumors of the parapharyngeal space. Head Neck Surg 1982;4:281-9.

32. Colreavy MP, Lacy PD, Hughes J. Head and neck schwannomas, a 10 years review. J Laryngol Otol 2000;114:119-24. 